\title{
O exótico e a viagem perfeita na figurativização fotográfica do destino turístico Curitiba-Brasil
}

\section{Cynthia Menezes Mello* José Manoel Gonçalves Gândara** \\ Universidade Federal do Paraná (Brasil)}

\begin{abstract}
Resumo: O apelo ao consumo do exótico no turismo, por meio de fotografias divulgadas pelos media, faz parte das estratégias o marketing de destinos na projeção de imaginários turísticos da viagem perfeita. O objetivo desse artigo foi investigar e discutir os efeitos de sentidos das figurativizações do tema do exótico corporificados nas fotos mostradas no site oficial do destino turístico Curitiba, visando compreender as estratégias utilizadas por esse enunciador que orienta a construção de distintos imaginários turísticos. As análises do site Curitiba Turismo foram realizadas, sob a tutela da semiótica discursiva e plástica, dita greimasiana, ampliada pelas concepções da semiótica visual. Como resultado, averiguou-se que à tática comunicacional visual adotada pelo enunciador foi tentar ressignificar os seus atrativos, por meio da produção de sentidos do exótico. Desta forma, apostando posicionar esse destino turístico como diferente de outros locais turísticos que detêm as mesmas características e, portanto, engendrando uma marca de viagem perfeita.
\end{abstract}

Palavras-chave: Exótico; Viagem Perfeita; Figurativização; Fotografia; Curitiba-Brasil; Semiótica.

\section{Exotic perfection in the photographic presentation of Curitiba-Brazil as a tourist destination}

Abstract: The exotic other as depicted in tourism marketing images forms part and parcel of the attraction of the allocentric tourist in search of the perfect trip of discovery. The aim of this paper is to analyse and discuss the sensual effects of the embodiment of the exoticism as reflected in the contents of the official website for the tourist destination Curitiba, and the underlying marketing strategies behind them. The Greimasian semiotic analyses of the official Curitiba tourism site are carried out using both written texts and images.to define how the exotic is forefronted in all the attractions. to differentiate the city from other similar tourist destinations in Brazil and conjuring up the perfect dream of discovery.

Keywords: Exotic; Perfect Trip; Embodiment; Photography; Curitiba-Brazil; Semiotics.

\section{Introdução}

É no turismo que o exótico se apresenta de maneira mais visível, saturado e atrativo, por meio de representações na visualização (o fazer ver) de fotografias da realidade cultural de um Outro ${ }^{1}$. Essas imagens fotográficas são difundidas midiaticamente através de mídias sociais, páginas da web, folders, guias de viagens, revistas especializadas, cartões postais, vídeos promocionais, programas televisivos etc. Elas se projetam no espaço midiático global e produzem afetividades, sonhos e fantasias, mas igualmente colaboram para a instauração de imaginários exóticos partilhados sobre lugares. Por sua vez, esses imaginários projetados midiaticamente, tematizam e figurativizam destinos ideais, ou seja, locais percebidos pelos sujeitos como perfeitos.

Neste caminho de reflexões, segundo Ferrari (2013) as fotografias se tornaram para o setor turístico um vigoroso instrumento publicitário para acionar os desejos e as fantasias dos sujeitos. Essas imagens fotográficas são captadas, selecionadas e voltadas para promover os ideais de consumo dessa esfera de negócios e, antes de tudo, utilizadas para oferecer uma fruição prazerosa da cena turística baseada na representação de figuras de paisagens (naturais e /ou culturais) e de objetos do universo de um Outro

* Universidade Federal do Paraná; E-mail: cynthiahotelaria@yahoo.com.br

** Universidade Federal do Paraná; E-mail: jmggandara@yahoo.com.br 
estrangeiro. Portanto, devem mostrar uma realidade turística que produza sentidos de locais distantes, preferencialmente, diferentes, isto é, destinos exóticos.

Sem meandros, as fotografias permitem representar o homem, o seu mundo e seus objetos, mas também, acumular e produzir informações e impressões sensoriais. Deste modo, elas atuam como fortes elementos simbólicos no consumo do turismo e agem também, na construção e produção de sentidos das marcas turísticas, exemplificado na figura, na fotografia abaixo, mostrada no site oficial do destino turístico $^{2}$ Curitiba (Curitiba Turismo, 2016).

Figura 01: Fotografia do Estufa do Jardim Botânico, Curitiba - PR.

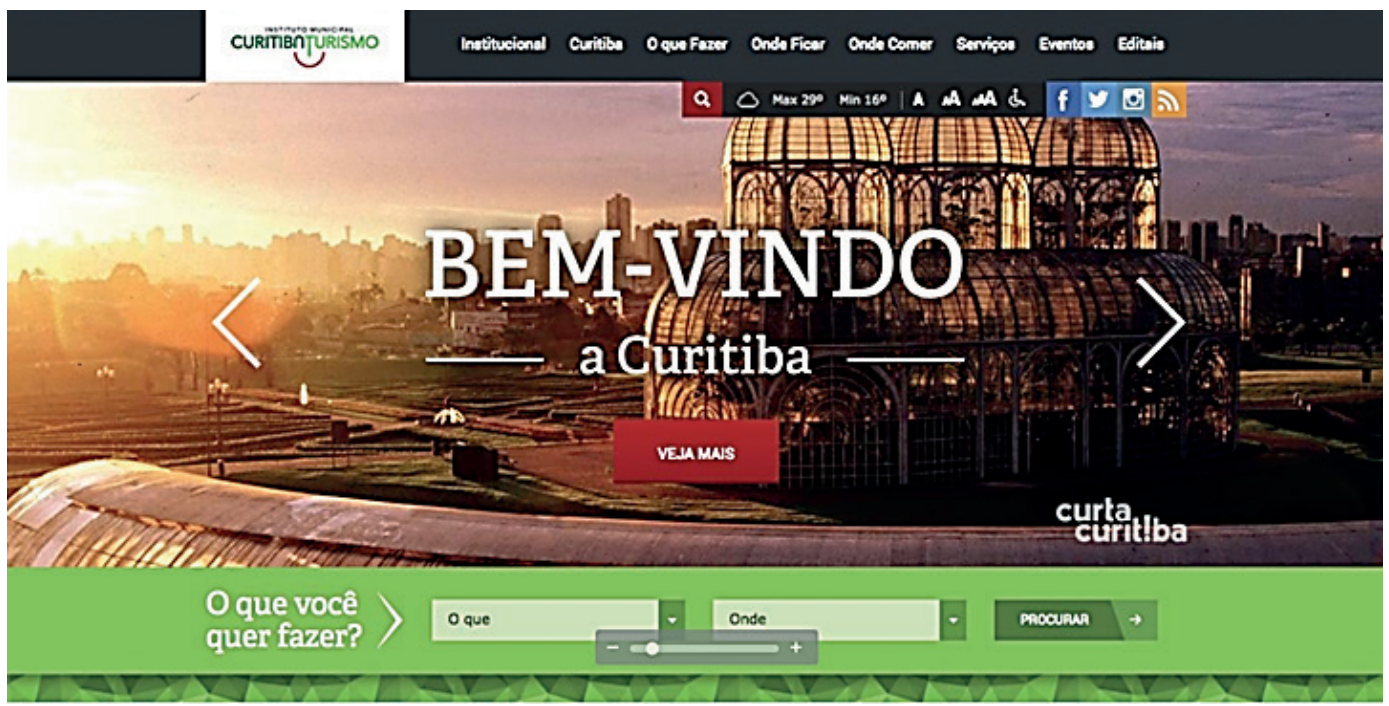

Fonte: Site Curitiba Turismo (2016).

Destaca-se que essa imagem retrata a Estufa do Jardim Botânico, reconhecida pelo setor turístico brasileiro, os media e os turistas, como uma das marcas desse destino (Ferrari \& Gandâra, 2015).

Assim sendo, infere-se que o convite ao consumo do exotismo no turismo por meio da visualidade fotográfica é uma das potentes estratégias do capitalismo globalizado, pois essa ação comunicacional modaliza um quadro de identidades, relacionamentos e de comunidades, tendo como ponto nodal a encarnação do imaginário da viagem perfeita cujos efeitos de sentidos (significados) tendem a determinar o sucesso mercadológico, ou não, dos destinos turísticos. Trata-se da materialização de um imaginário que pode ser compreendido como o ideal de todos os viajantes em realizar em uma experiência única de viagem a "evasão do Mesmo, em busca da felicidade no paraíso através do prazer, do divertimento e do jogo de alteridades para dar sentidos para a vida" Ferrari (2013: 141). Dessa forma, amplia-se a noção de Hiernaux-Nicolas (2002) que os ideais turísticos estão voltados à busca da felicidade, do desejo de evasão, do descobrimento do Outro e do regresso à natureza.

Amirou (2007:17) explica que "é nas viagens para os países pobres que se evidencia mais claramente o fantasmático que funda a corrida rumo ao sol e a predileção pelo exotismo". Esta é a razão de alguns destinos brasileiros vinculados ao segmento sol e mar, serem quase sempre concebidos midiaticamente como paradisíacos, distantes e perfeitos, logo, exóticos. É importante destacar que a temática sobre o imaginário turístico, especificamente, no víeis do exotismo corporificado na fotografia turística, ainda é pouco explorada nos estudos do marketing de destino, embora seja inegável seu valor para capturar os complexos fatores subjetivos atuantes no consumo turístico contemporâneo.

No entanto, ser um local paradisíaco e longínquo será a única figurativização e inscrição de sentidos do consumo do exotismo no turismo? Como os sentidos do exótico são figurativizados nas fotografias de forma que se tornem em marcas turísticas em Curitiba? 
Esse artigo teve como objetivo investigar e discutir os sentidos das figurativizações do exótico corporificados nas fotos mostradas no site oficial do destino turístico Curitiba, visando compreender as estratégias fotográficas utilizadas pelo enunciador que orienta a construção de distintos imaginários turísticos. Almejou-se apresentar um modelo de análise com base na semiótica para sublinhar alguns traços figurativos dessa predileção contemporânea de consumo por tudo aquilo que se reveste de caráter exótico materializado na visualidade das fotografias dos destinos turísticos, aos quais produzem imaginários e os discursos das marcas turísticas da Viagem Perfeita.

\section{Considerações sobre o imaginário do exotismo no turismo}

Evidencia-se que o apelo ao consumo do exótico nas experiências em viagens, não é algo novo, embora seja discursivizado e manifestado, contemporaneamente, como tal. É um discurso ressignificado pelo setor do turismo que se remete ao imaginário do paraíso construído pelo europeu do Ocidente, cuja origem encontra-se nas narrativas das viagens ao Novo Mundo (Santos 2013; Aun, 2010).

Sendo assim, o exotismo nas viagens é um discurso antigo e está relacionado ao "estrangeirismo", mas também a algo que é "esquisito, extravagante, excêntrico" e constela no universo dos imaginários do turismo. Ou seja, aquilo que vem de fora, do longínquo e tende a desvincular o sujeito do seu cotidiano, provocando um embate imaginoso, simbólico, com um Outro externo, portanto, exótico (Houaiss, 2001: 235).

Berghe \& Keys (1984) são os primeiros estudiosos a relacionar o exotismo ao consumo do turismo étnico. Eles observam que a busca pelo exótico por turistas é inerente à fronteira étnica que os separam dos nativos, cujo interesse não é a procura do exotismo étnico, pois para eles pouco importa se o objeto turístico é autêntico. Os autores concluem que o produto básico do turismo é o exotismo. Destaca-se que isso ocorre porque no turismo o contato com o Outro sempre se dá através de uma barreira cultural. Portanto, trata-se do exótico naturalizado nas práticas turísticas cujos elementos que o constitui fazem parte do imaginário turístico.

Mais recentemente, Amirou (2007: 191) destaca que o exotismo no turismo contém características fantasmáticas e o "imaginário exótico existe para apreender e incorporar um "alhures" geralmente percebido como ameaçante". Ele elucida que exotismo funciona como um objeto transicional e o que realmente seduz às pessoas não é tanto a imagem do exótico, "banalmente estereotipada", mas a "ideia de passagem, induzida pela relação de um mundo baço e um mundo colorido". Para Amirou (2007) a invenção de países e destinos exóticos pelo setor do turismo é uma ilusão útil aos ditames mercadológicos do setor; e para o turista, um facilitador para a apreensão do desconhecido. O que importa não são as particularidades de um destino turístico, pois são bastante esquemáticas, mas o fato desse local representar uma alteridade e propiciar uma fantasia de fuga possível do cotidiano. $\mathrm{O}$ "exotismo surge como aquilo que facilita e torna ansiogênica a apreensão do desconhecido" (Amirou, 2007: 191-192).

Pode-se acrescentar que o exotismo nas viagens ocorre por meio de ações das alteridades e dos alhures percebidos como angustiantes, estes dois tópicos geraram o exotismo do longínquo, cujo modo de funcionamento é muito similar ao objeto transicional descrito por Winnicott (1975) quando explica que o espaço potencial é um lugar imaginário, onde a realidade pode ser reelaborada e reorganizada através de atividades simbólicas.

O turismo e a viagem constituem um espaço de "possibilidades", e de "reorganização imaginária e simbólica de si, do outro e dos alhures", segundo Amirou (2007: 11). Dessa forma, é vital definir a ideia de alteridade para este estudo, abarcada - em uma perspectiva socioantropológica - como uma somatória de diferenças objetivas e subjetivas que o eu percebe no Outro, em que se fundamenta a relação entre alteridade e exotismo nas diferenças entre eles. Porém, Ferrari (2013) evidencia que esse único ponto de vista não basta para definirmos o exotismo nas viagens. Há que se levar em conta outros elementos, como a atração do longínquo, que é também uma das marcas da inscrição exótica.

Sobre esse viés, Freitas (1987:180) salienta que a "importância do longínquo e de sua relação com a idealização do Outro na teoria do exotismo é incontestável". Na apreensão da alteridade existem dois valores essenciais que tecerão os símbolos emblemáticos sob os quais o Outro turístico será percebido e imaginado como exótico: o longínquo e o maravilhoso, este último nos seus dois pontos fundamentais: "a bondade e a beleza paradisíaca de um lado, e o monstruoso, ou pelo menos o estranho, do outro" (Freitas, 1987: 182).

Freitas (1987: 181) evidência outro ponto como a relevância da "ideia de estranheza na composição do tema de exotismo", mas também, a busca pelo sagrado, de um centro visando a supressão dos signos que lembram o cotidiano Amirou (2007). Assim sendo, o imaginário do exótico no turismo é constituído 
por uma complexa constelação discursiva de produção de sentidos. São inscrições simbólicas resultantes de vários elementos que produzem diversos significados, tais como: o longínquo e o paradisíaco contemplando também representações de alteridade, dos alhures, do estranho e do sacro. Estes, por sua vez, desmembram-se nos sentidos dos elementos de beleza paradisíaca, dos jogos e o jogo de identidade e da felicidade exótica (Ferrari, 2013; Amirou, 2007; Freitas, 1987).

A ideia da viagem perfeita deve ser compreendida como uma complexa rede comunicacional que ampara e flexibiliza os elementos que compõem os imaginários turísticos, atuando nas imagens dos destinos turísticos, de tal modo que para Ferrari (2013: 257) "tornou-se uma marca turística materializada nos discursos dos media de turismo". Já a marca "alimenta a dimensão dos sujeitos ligada aos vínculos afetivos da viagem, da imaginação, e lhe dá formas diversas". Abarca todos os tipos de segmentos possíveis da viagem. Está também ligada à dimensão da "paixão pela viagem, da ordem do sensível". Mais do que isso, "é o ponto nodal que costura os discursos midiáticos do turismo". Isto é, "os ideais turísticos naturalizados pelo imaginário em suas três dimensões de partilha desse sensível: o turista, o setor e os media de turismo" (Ferrari, 2013: 257).

Semprini (2009) e Perez (2006) $)^{4}$, também referenciaram algumas concepções sobre as marcas contemporâneas. As palavras de Semprini (2009: 104) endossam a concepção de Ferrari (2013) quando ele define a marca como "um conjunto de discursos relativos a ela pela totalidade dos sujeitos (individuais e coletivos) envolvidos na sua construção". Na mesma perspectiva, Perez (2006) elucida que a marca é um vínculo simbólico estabelecido a partir de relações e experiências compartilhadas com seus públicos, e que cada vez mais, está aberta à construção coletiva. Portanto, entende-se que a marca da viagem perfeita é uma obra coletiva, constantemente, ressignificada visando atender as expectativas do setor, dos media e turistas-consumidores.

Para o entendimento das proposições sobre o processo de produção de sentidos do imaginário do exótico da viagem perfeita, especificamente, a do olhar do visitante e do olhar do visitado, dos alhures, paraíso e da felicidade exótica, partiu-se dos pontos de vistas teóricos em diversos autores Ferrari (2013); Auon (2010); Amirou (2007); Hiernaux-Nicolas (2002); Urry (1997); Landowiski, (1997). Com essa abordagem demonstrou-se o funcionamento dessa semiose por meio de interações estabelecidos entre os olhares do visitado versus do visitante, cujas implicações geram os sentidos da temática do exótico no turismo. Comprovou-se que esses significados colaboram na construção de valores sociais e culturais e na (re) construção de imaginários exóticos para os destinos turísticos. Assim, conseguiu-se sancionar que esses sentidos são instigados, a partir das relações figurativizadas nas corporalidades fotográficas dos media em turismo que estabelecem certos diferenciais para os locais turísticos e a marca da viagem perfeita. Isto é, esse conjunto de efeitos são produzidos pelos elementos constituintes da temática do exotismo turístico caracterizado como espaço do Outro. Mas, também, que eles se incorporam nos produtos e serviços do setor turístico como marcas, causando os sentidos dos discursos verbivisuais das viagens perfeitas (Ferrari, 2013).

\section{Procedimentos metodológicos}

Esse estudo tem caráter qualitativo e exploratório, metodologicamente organizado por revisão bibliográfica e documental. Foram realizadas análises das fotos do site Curitiba Turismo, sob a tutela da semiótica discursiva e plástica, dita greimasiana ${ }^{5}$, adensadas pelas concepções da semiótica visual, com base nos estudos de Floch $(2001 \mathrm{a} ; 2001 \mathrm{~b})^{6}$ e Pietroforte $(2008 ; 2010)^{7}$. A semiótica greimasiana, na perspectiva da semiótica visual foi escolhida como método para análise do corpus porque estuda a significação tendo como objeto o texto (verbal ou não) e o seu sentido, com o intuito de complexizar e adensar a apreensão dos significados dos discursos. Mas também, a semiose (processo semiótico) do exótico nas fruições fotográficas turísticas. A semiótica pretende apreender como se dá a construção dos sentidos do texto.

Para os aportes sobre o discurso visual turístico na construção da viagem perfeita, a sustentação metodológica se deu a partir das pesquisas de Ferrari $(2013)^{8}$, e dos conceitos de imaginários turísticos e exotismo amparados por Amirou $(2007)^{9}$, Hiernaux-Nicolas $(2012)^{10}$, Freitas $(1987)^{11}$ e Segalen $(1989)^{12}$.

O texto em semiótica é compreendido como qualquer objeto, portanto, quando se analisa um texto fotográfico nessa abordagem, trata-se de descrevê-lo a partir de um percurso gerativo de sentido, em articulação entre um plano de expressão e um plano de conteúdo. O plano de conteúdo alude-se ao "significado do texto", já o plano de expressão refere-se à manifestação do conteúdo em um "sistema de significação verbal, não verbal ou sincrético" (Pietroforte, 2010: 11). 
Neste sentido, compreende-se neste estudo que os enunciadores midiáticos turísticos mobilizam certos procedimentos discursivos verbivisuais para tematizar e figurativizar valores sociais e culturais em suas estratégias comunicacionais. Tematizar é formular certos valores de maneira "abstrata e organizá-los em percursos", enquanto figurativizar é "trazer uma imagem para representar as experiências vividas" nesses percursos por figuras Loose\&Peruzzolo (2008: 6). As figuras materializam "sensorialmente os temas e dão a eles "corporalidade". Os temas abstratos são "recobertos" por traços semânticos "sensoriais" de cor, de forma, de cheiro, de sons etc." (Barros, 2004:14).

A noção dessa semiose pode ser ampliada, compreendendo-se que a tematização e a figurativização fazem parte da produção de sentidos de um dado discurso. Logo, "essa abstração é concretizada pelo revestimento figurativo que cria um efeito de realidade, pois constrói uma imagem do real e representa, assim, o mundo" e expresso nas fotografias do site, ou em outros suportes midiáticos (Lucena, 2000: 42).

Assim, metodologicamente, buscou-se desconstruir essa semiose dos textos fotográficos presentes no site Curitiba Turismo. Visou-se analisar e identificar como o exótico em seus elementos imaginais, se tematizam nas figurativizações das fotos e de que maneira eles se corporificam nos atrativos de Curitiba. Mas também, aspirou-se conhecer, de que forma esse processo de apreensão de sentidos do exótico são figurativizados nas fotos e pode ser interpretado pelo observador como viagem perfeita, por meio da estratégia do enunciador-governamental.

Primeiro, partiu-se da apreensão da tematização abstrata do exótico (em seus elementos) nas fotos, para em seguida identificar quais imagens foram trazidas para representar o exótico, ou seja, figurativizar o tema, que se dá através de figuras. Essas figuras foram corporificadas nas superfícies fotográficas por meio de arranjos plásticos constituídos por elementos cromáticos (cores), eidéticos (formas) e topológicos (posição), que combinados entre si produzem à percepção visual de uma imagem, portanto de uma determinada cena turística. Deste modo, conseguiu-se identificar por meio desses arranjos plásticos quais foram os efeitos produzidos de realidade nas fotografias selecionadas pelo enunciador-governamental para oferecer uma ilusão de serem copias do real em Curitiba.

Euforiza-se, que a construção e apreensão desse imaginário do exótico na viagem perfeita, na perspectiva semiótica, também ocorre por meio das relações de oposições de sentidos produzidas entre os olhares do visitante e do visitado, cujos efeitos de significados atuam no engendramento do posicionamento e da marca da viagem perfeita. Assim, elaborou-se um modelo de análise dos principais elementos figurativos de cada complexidade teórica enfocada sobre o imaginário do exótico da viagem perfeita por meio de um quadro ilustrativo visando facilitar, pedagogicamente, a apreciação do objeto de estudo. O intuito foi organizar e sintetizar as diversas concepções dos autores citadas antes, cujos conceitos guiaram estas discussões, mas igualmente, como um fio condutor para operar outras apreciações semióticas similares a desta pesquisa. Essa ação foi essencial para aparelhar e facilitar a compreensão das análises semióticas das fotografias do site Curitiba Turismo realizadas por este estudo, om ênfase nos traços semânticos visuais (cor, forma e posição) que usados em arranjos plásticos, deram corporalidade ao tema do exótico no turismo.

Cabe agora, apresentar o modelo de análise do imaginário do exótico da viagem perfeita por meio de um quadro ilustrativo que demonstrará o processo de interações estabelecidas entre o olhar do visitado versus o olhar do visitante, cujos efeitos geram os sentidos da temática do exótico no turismo, para posteriormente, ganhar vida, ou melhor, corporificar-se e materializar-se nas fotografias do site Curitiba Turismo (2015), enquanto viagem perfeita.

A par da semiose do imaginário do exótico da viagem perfeita apresentado, ratificou-se que esse conjunto de efeitos são produzidos pelos elementos constituintes da temática do exotismo turístico caracterizado como espaço do Outro. Mas, também, que se incorporam nos produtos e serviços do setor turístico como marcas, causando os sentidos dos discursos verbivisuais das viagens perfeitas Ferrari (2013). Concomitantemente, demonstrou-se no modelo o processo de interações estabelecidas entre o olhar do visitado versus o olhar do visitante, cujas implicações geram os sentidos da temática do exótico no turismo. Esses significados colaboram na construção de valores sociais e culturais e na (re) construção de imaginários exóticos para os destinos turísticos. Portanto, sanciona-se que esses sentidos são instigados, a partir das relações figurativizadas nas corporalidades fotográficas dos media em turismo que, tendem a estabelecer certos diferenciais para os locais turísticos e a marca da viagem perfeita.

Por fim, às palavras de Landowiski (2009:9) endossam à escolha da semiótica como método de análise desta pesquisa, em razão da necessidade de tentar explicar "as condições de emergência do sentido nos discursos e nas práticas significantes mais diversas", logo, nas práticas turísticas. A semiótica se 


\section{Quadro 1: O imaginário do exótico da viagem perfeita}

$$
\text { Vs. }{ }^{13}
$$

\begin{tabular}{|l|}
\hline Visualização do visitado \\
É manifestada pelo modo com que as pessoas veem o destino e \\
seus imaginários sobre o local, sejam elas a comunidade local \\
ou os gestores da atividade turística. \\
\hline Produção de olhar autêntico \\
É produzido e manifestado pelo olhar das pessoas que vivem \\
no destino e seus imaginários sobre o local. Pode-se dizer que \\
a comunidade local possui o olhar natural, que representa \\
a Identidade, o autógeno, a cena social onde se vive. São os \\
imaginários turísticos. \\
Produção do olhar do turismo \\
É produzido e manifestado pelo olhar das pessoas que vivem \\
e administram o destino turístico e seus imaginários. Pode-se \\
dizer que os gestores turísticos são os responsáveis pelo olhar \\
construído, uma construção mercadológica e midiática do modo \\
de ver paisagens turísticas. \\
São os imaginários turísticos.
\end{tabular}

\section{Produção do outro turístico}

Projeção (simulação) de uma superficie, de um outro autêntico, que recebe os sujeitos em suas viagens. Se apresenta apropriadamente constituída para receber (no espaço) e agendar (no tempo) as experiências dos sujeitos-turistas.

Produção do imaginário do exótico

É produzido e manifestado pelo distante, diferente, o

desconhecido, o mitificado, diverso do cotidiano.

\section{Figurativização do longíquo}

Figuras de locais distantes do cotidiano. Os espaços turísticos. Representa o escape, fuga do dia a dia.

Figurativização da alteridade

Figuras do estrangeiro, desconhecido. Identidade. O que está

fora. Representa o mundo estrangeiro

Figurativização dos alhures

Representa o desinteresse interessado de olhar o de lá.

Figurativivização do diferente

Figuras daquilo que é dessemelhante, desigual, diverso do cotidiano das pessoas e, por isso, torna-se inquietante. Podem ser figuras da arquitetura urbana, da natureza ou de pessoas e culturas.

\section{Figurativização do sagrado} virtudes regenerativas, eletivas e fascinantes como figuras de locais sagrados: montanhas, florestas, cachoeiras, entre tantos outros sítios pródigos da natureza. As grandes realizações monumentos, etc.
Figura de outra parte. Outro momento. Noutro lugar.

Certas áreas geográficas precisas, às quais lhe são atribuídas da humanidade, como as pirâmides, as catedrais, os grandes

\section{Visualização do visitante}

É manifestada pelo modo com que os visitantes veem o destino turístico, bem como seus imaginários sobre estes destinos.

\section{Produção do olhar turístico}

É produzido e manifestado pela composição do olhar social, vertical e do eu, a alteridade, o outro, a cena social de um estrangeiro, longe do cotidiano. É a construção mercadológica e midiática dos viajantes visualizarem e apreenderem a produção de sentidos das paisagens turísticas. São os imaginários dos turistas.

\section{Produção do outro autêntico}

Projeção (simulação) de uma superfície, de um outro antropológico, que recebe os viajantes para vivenciarem uma experiência vivificadora ligada a essência do lugar.

\section{Produção do imaginário da viagem perfeita}

É produzido e manifestado pelo paraíso turístico, pela beleza estética, pela felicidade, pelo entretenimento.

\section{Figurativização do paraíso turístico}

Figuras de espaços Turísticos. Paisagens tropicais, bonitas, insulares. Visão do jardim do Éden, celestial. Regiões, cidades, locais e espaços de compras, sacro, de diversão, etc.

Figurativização da beleza paradisíaca

Figuras de beleza ligadas à fruição estética. Paisagens da natureza exuberantes ligadas a imagens dos trópicos. Belas praias, vegetação vivaz, locais quentes e ensolarados, rica fauna, et. Sol ardente e águas calmas e transparentes. Paisagens urbanas constituídas pela natureza e cultura: Parques, bosques e jardins.

Figurativização do espaço dos jogos e dos jogos de identidade

Figuras de espaços turísticos como espaços de jogos, onde os viajantes podem vivenciar os aspectos lúdicos e fantasiosos do eu. Dividido em espaço-real (figuras de recintos recreativos, parques temáticos, estádios, resorts, navios, praias, etc.) e espaço-virtual (figuras de espaços abertos para vivenciar experiências, encenar múltiplas máscaras identitárias, se divertir e ter prazer.

Figurativização da felicidade exótica

Figuras que representam o hedonismo, o prazer, a diversão e a Felicidade. Jogo de alteridade. Espaços turísticos.

Fruição. Figuras de Imagens de gente contente, sorridente. Dias ensolarados, praia, mar, sol, piscina, navios, ilhas, palmeiras, etc. Montanhas, neve, céu azul. Cultura, natureza, história, compras, diversão, esportes radicais e aventura. Entretenimento, Gastronomia. Parques temáticos; Cassinos em Las Vegas, Punta Del Leste.

\section{Posicionamento do destino turístico}

Para o posicionamento de suas marcas, o setor turístico faz uso frequente da construção de imaginários exóticos, como um diferencial dos destinos, objetivando instituir conexões de sentidos com seus públicos alvos a partir da promessa de prazer e hedonismo. Isso se dá com simulações de lugares paradisíacos e felizes, longíquos, diferentes do cotidiano, ou seja, aquilo que está fora.

\section{Marca da viagem perfeita}

É o ideal de viagem de todos os viajantes: realizar em uma única experiência a fuga do mesmo, encontrar a felicidade no paraíso turístico através do prazer, do divertimento e das máscaras turísticas, encarnadas visando aflorar a manifestação do eu.

Fonte: Elaborado pelos autores ${ }^{14}$. 
apresenta como uma disciplina com um ponto de vista "empírico e descritivo", uma entre outras, no campo das ciências humanas. Como observa Landowiski (2009), "próxima da linguística e da antropologia", a semiótica tem possibilitado uma "metalinguagem de modelos que permitem não descrever as coisas em si mesmo, mas a maneira em que se tornam significativas projetando sobre elas um olhar que organiza as relações", como o olhar do visitante e o do visitado. Essa mudança de abordagem é o que fundamenta a especificidade do campo semiótico, institui igualmente os seus limites quando proíbe estabelecer regras sobre "o ser", pois "temos de limitar e analisar, comparar, interpretar os dispositivos simbólicos através dos quais a realidade faz sentido para os sujeitos", no caso deste estudo, o exótico no consumo do turismo por meio das fotografias (Landowiski, 2009:9) ${ }^{15}$.

\section{Análise da semiose fotográfica do imaginário exótico da viagem perfeita}

Para melhor exemplificar o modelo de análise no quadro ilustrativo exposto, também, optou-se em demonstrar, de que forma se dá a construção e materialização desse processo discursivo visual na produção de sentidos da tematização, da figurativização e da corporificação do exótico nas fotografias selecionadas pelo enunciador-governamental que visam posicionar Curitiba como destino turístico. Buscou-se, explicar como os enunciatários-interpretes tendem a semiotizar esses sensíveis fotográficos. Ou seja, o olhar do visitado vs. o olhar do visitante.

Assim sendo, ratifica-se que o modelo de análise no quadro ilustrativo funciona como um mapa sintético dos possíveis significados causados pelo conjunto dos elementos temáticos do imaginário do exótico e do imaginário da viagem perfeita, cujos efeitos de sentidos dos arranjos plásticos - fruto das escolhas do enunciador - figurativizam o diferencial para os destinos se mostrarem como a marca da viagem perfeita. Essas figurativizações nas fotografias produzirão identidades distintas para os lugares se diferenciarem, portanto, posicionarem suas marcas. Por outro lado, destaca-se que o corpus deste trabalho, as fotografias publicadas no site Curitiba Turismo são inúmeras, portanto, elegeu-se por recortar a parte superior do site e destacar as fotos utilizadas no banner que evidência e sintetiza as principais discursivizações verbivisuais exóticas do enunciador-governamental na promoção da marca da viagem perfeita. Realizou-se, também, outros cortes específicos nas fotos escolhidas, para melhor apresentar os elementos analisados.

Essa superfície midiática do site é coberta por três distintas imagens fotográficas selecionadas pelo enunciador-governamental para figurativizar as paisagens turísticas do destino turístico Curitiba, com o intuito de apresentar os atrativos da urbe como exóticos e perfeitos. São elas na sequência das aparições no site:

Figura 02: Fotografia da Ópera do Arame, Curitiba - PR.

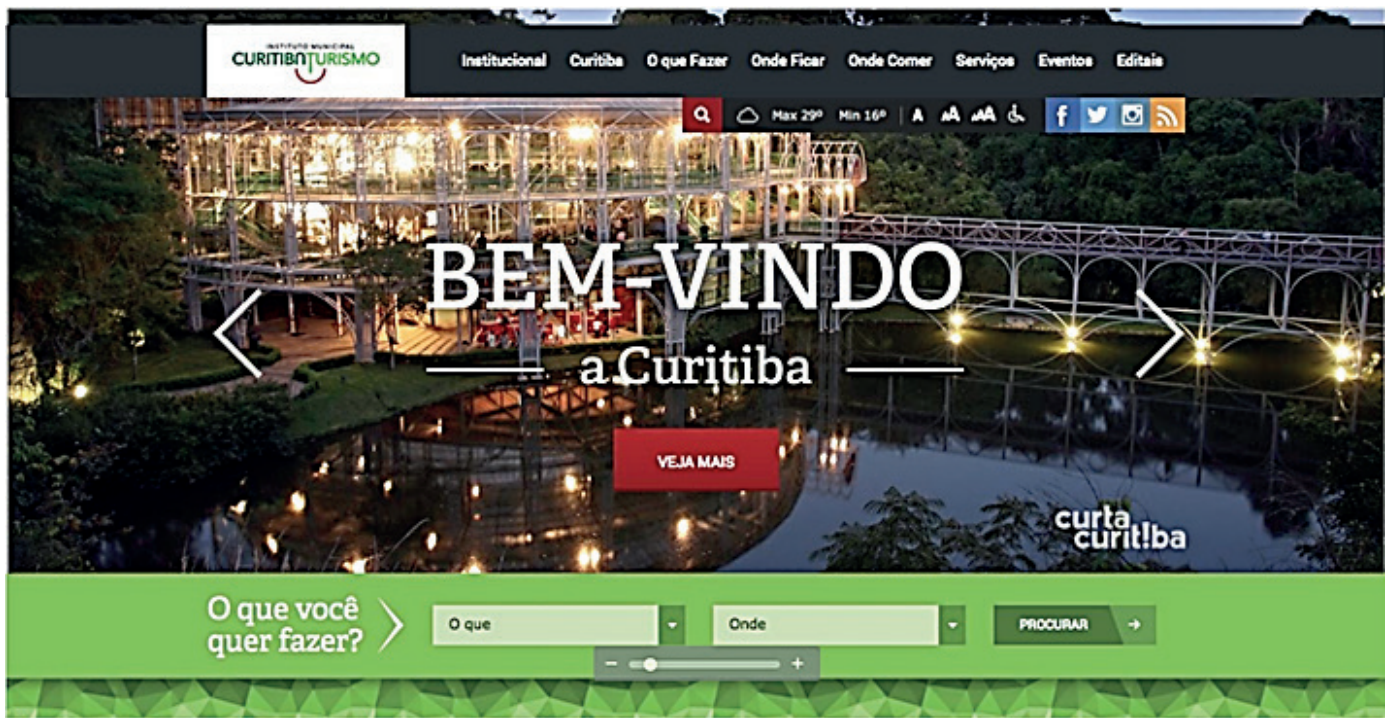

Fonte: Site Curitiba Turismo (2016). 
Figura 03: Fotografia do Parque Tanguá, Curitiba - PR.

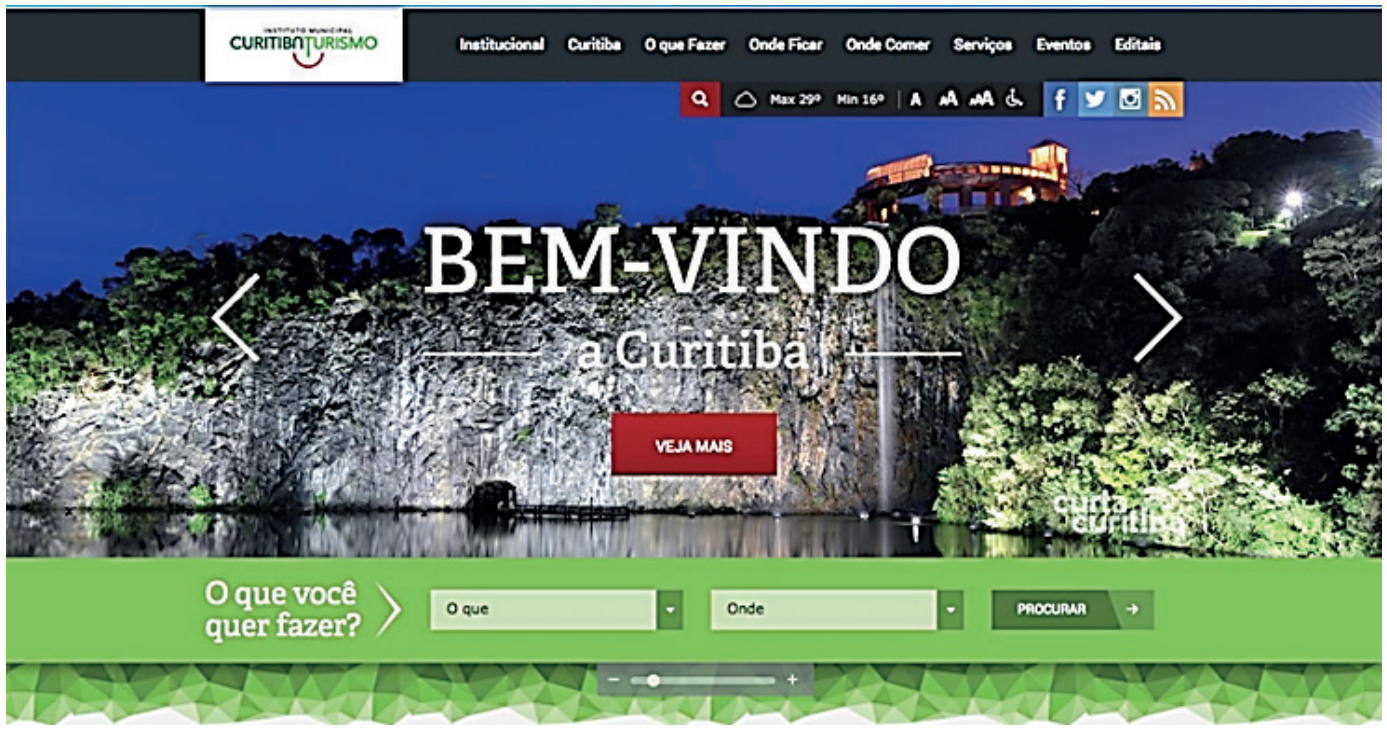

Fonte: Site Curitiba Turismo (2016).

Figura 04: Fotografia do Estufa do Jardim Botânico, Curitiba - PR.

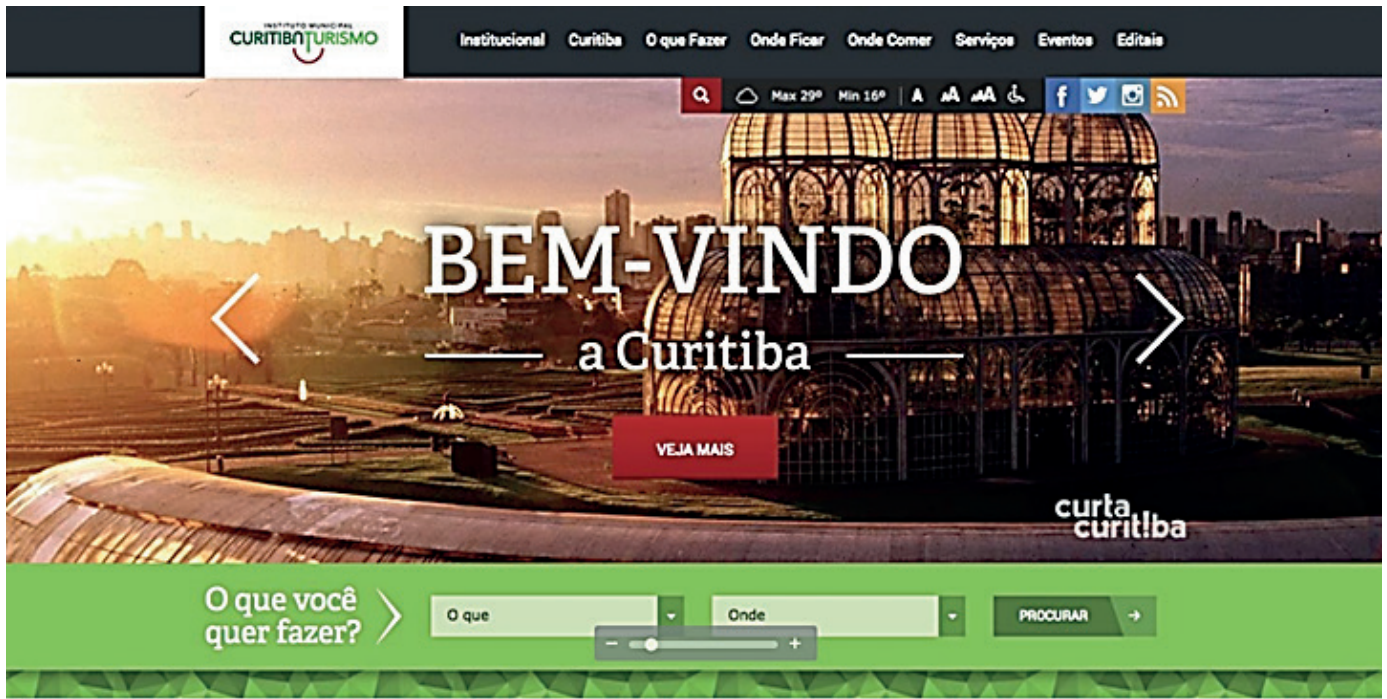

Fonte: Site Curitiba Turismo (2016).

Esta seleção fotográfica é proposital, uma vez que sugere à intenção do enunciador em narrar visualmente uma minibiografia turística do destino por meio desse conjunto imagético que plana no display. $\mathrm{O}$ enunciador busca manifestar visualmente os dotes turísticos curitibanos miniaturizados nesses instantâneos como Outro turístico ${ }^{16}$, por produzir sentidos de longínquo. Além disso, o enunciador traça outra estratégia por meio desta sequência de fotos: construir um imaginário turístico da cidade ressignificado visando romper com o modelo tradicional, usualmente utilizado pelo marketing de destino curitibano de mostrar nos materiais promocionais como primeira opção fotográfica, o seu principal 
cartão-postal: a Estufa do Jardim Botânico, segundo Mello \& Gândara (2015). Trata-se de uma imagem intensamente publicizada que tem um vigoroso potencial comunicacional e fantasmático de sobrepor-se as demais de Curitiba (Ferrari \& Gândara, 2015).

Assim, exibe-se na figura 2, na primeira foto, a Ópera do Arame, em sequência, na figura 3, o Parque Tanguá e, por fim, na figura 4, o fotograma da Estufa do Jardim Botânico (figura 4). Embora esta última fotografia, não seja a primeira alternativa de visualização do banner foi incorporada na exposição por ser uma das importantes marcas turísticas visuais de Curitiba. Dessa forma, por meio das três fotos, o imaginário exótico se corporifica nesse display midiático figurativizando o longínquo do Outro, já que a razão da existência do site é a promoção turística da cidade, logo, distante do cotidiano dos turistas. Já à tática de alternância das fotografias, também tem um motivo de ser, pois é no ir e vir, rapidamente, das imagens que, segundo Freitas (1987) se captura à atenção do enunciatário, produzindo os alhures como explicam Amirou (2007) e Landowiski (1997). Isto é, o de lá da cena turística curitibana, outro elemento vital na produção e constituição dos sentidos do exótico. Igualmente, conclui-se que esta estratégia produz o olhar turístico. Um modo construído pelos enunciadores do setor de que maneira os enunciatários devem visualizar as imagens reais e virtuais turísticas (Ferrari, 2013).

O olhar turístico é composto pela conjunção do olhar social, vertical e do eu, e está vinculado aos imaginários turísticos na apreensão dos observadores sobre a alteridade de ser turista e na projetação da superfície do Outro turístico, cujos efeitos de sentidos tendem ser interpretados por esses observadores como um Outro autêntico. Trata-se, segundo Ferrari (2013) da apreensão pelos turistas da projeção de uma superfície, como um outro antropológico, que recebe os viajantes para vivenciarem uma experiência vivificadora ligada a essência do lugar. Também é importante evidenciar que o enunciador com esta tática atribuí verosimelhança às fotos mostradas e proporciona efeitos de realidade. Assim euforiza-se os significados de paraíso turístico e beleza exótica ao destino turístico que são outros componentes do imaginário do exotismo no turismo. No caso de Curitiba são paisagens urbanas formadas por meio da natureza e da cultura (parques, bosques e jardins), porém incomuns de serem vistas na maioria das grandes metrópoles pelo mundo. No banner do site Curitiba Turismo, observa-se que ele é topologicamente distribuído da mesma maneira nas três fotos utilizadas pelo enunciador. Trata-se de uma distribuição, posição e orientação das formas e do movimento no espaço das figuras que ocorrem por meio dos contrastes: englobante vs. englobado alto vs. baixo, esquerda vs. direita, grande vs. pequena, central vs. periférico, frente vs. atrás. Detalhando esse processo, na imagem da Ópera do Arame, forma-se, acima e em baixo, uma moldura constituída por elementos eidéticos cujos efeitos visuais conduzem a visualização da fotografia e a fruição da página pelos enunciatários. Os elementos eidéticos constroem as formas plásticas por meio dos contrastes: curvo vs. retilíneo, côncavo vs. convexo, ascendente vs. descendente, como observa-se nas três imagens no banner.

No topo da superfície midiática, como observado na figura 02 , uma linha continua e suave, na cor verde cumpre a tática visual de delimitar o espaço de visualização e, remeter o enunciatário à ideia do verde, presente na natureza da cidade. Mas principalmente, compete deslocar o olhar do enunciatário para baixo, em direção aos enunciados verbais que ancoram os imaginários construídos sobre Curitiba. Assim, primeiro, o olhar encontra uma barra em branco, onde se vê inserido, à esquerda o logotipo da cidade de Curitiba e, no outro extremo, destacado no mesmo tom de verde da linha do horizonte, o link de procura de conteúdos do site.

Seguindo este deslocamento provocado no olhar do enunciatário, em direção abaixo, à esquerda, um pequeno box na cor branca, em formato retangular, estampa o logotipo do site Curitiba Turismo, por meio de dois tons de verdes, contrastantes entre si e com o branco. No centro, a letra grafada " $T$ " desce alguns centimetros, desenhando um nariz, e logo abaixo, uma linha concova ligando as letras "b" e "u", em vermelho vibrante, que desenha um sorriso, causando a impressão da popular figura do smiles, muito utilizada nas redes sociais para euforizar sentidos positivos de mensagens. Também, nesta ação visual o ideal de cidade verde é ressignificado e projeta os enunciatários na concepção de destino feliz, local de gente feliz, logo, sugere a existência da felicidade exótica neste destino turístico. Porém, o olhar do enunciatário não para neste ponto da página e segue até encontrar a maior superfície do banner, onde estão incorporadas as fotos alternadas dos principais atrativos exóticos: A Ópera do Arame, o Parque Tanguá e a Estufa do Jardim Botánico.

Já na parte inferior da superfície do site, como observado na figura 03, na foto do Parque Tanguá, sobressai-se outro importante elemento eidético compondo o arranjo visual, ou seja, a tática publicitária. Uma pequena bandeira é encravada sobre as fotografias formando novamente uma linha continua, por meio do embate cromático com a imagem, mas agora, no tom de verde mais vivo, o mesmo da identidade cromática visual do site. Dessa forma, força-se um movimento, ao contrário do olhar do enunciatário para cima. Esse display linear, também compete restringir, em um primeiro momento, o espaço visual, mas igualmente, incitar o olhar para cima. A finalidade tática visual é concentrar, saturar o olhar turístico na visualização da cena 
fotográfica, para em seguida, voltá-lo para o outro enunciado menor: "O que você quer fazer". Novamente, o matiz verde é selecionado para acompanhar à proposta do enunciador em ressaltar as qualidades ambientais naturais da cidade de Curitiba, como o destino ideal, por ser a urbe mais arborizada do País.

No entanto, para carregar o olhar turístico dos enunciatários e produzir os sentidos dos discursos visuais da viagem perfeita, como observado na figura 04, outra tática é concebida pelo enunciador, por meio de uma ancoragem verbal. Com um grande enunciado de "BEM-VINDO", grafado em letras caixa alta, na cor branca, se produz o choque necessário na palheta de cores das fotos para destacar o apelo passionalizador (emoções) visual de consumo do exótico nesse destino turístico. Na verdade, o enunciador quer causar efeitos de sentidos de hospitalidade, ou seja, de acolhimento na visualização da página. Para reforçar essa apreensão pelos enunciatários, logo abaixo, em letras brancas menores são inseridos dois travessões para euforizar quem acolhe: "a Curitiba".

Outros dois grandes sinais, de mais e de menos, também são marcados nessa superfície e centralizam a declaração de acolhimento, de tal modo que esses símbolos agem limitando o campo visual, para em seguida, empurrar o olhar do enunciatário para o fundo da imagem. Nela se corporificam as fotografias dos atrativos turísticos idealizados pelo site como: perfeitos, logo, ascendendo o imaginário do exótico de Curitiba e a projeção da marca da viagem perfeita. Esta estratégia, não se detém nesse ponto, pois o enunciador, ainda aposta na ideia de que o enunciatário fruiu essas imagens fotográficas e gostou. Assim, provoca-se visualmente outro movimento, agora ao contrário, puxando o olhar do enunciatário para frente, onde se vê um pequeno box, destacado pelo tom vermelho, que realiza o convite de: Veja Mais, isto é, prove mais, Curitiba. Por fim, do lado direito, no final da superfície do display, encontra-se mais um pronunciado do enunciador, em letras minúsculas, na cor branca, que chancela a fantasia de: curta Curitiba.

\section{Os resultados das análises da visualização do visitado e do visitante}

Como evidenciado no modelo de análise (quadro 1), o olhar do turismo constrói figuratividades da temática do exótico que ganham vida (corporalidade) e cobrem as superfícies das fotografias mostradas no site, cujos efeitos de sentidos produzem realidades que lá é assim. Materializa-se, portanto, o conjunto de elementos que formam o imaginário turístico do exótico como um diferencial para o destino turístico de Curitiba, no víeis do olhar do visitado.

\section{A figurativização fotográfica do longíncuo}

O longinquo ${ }^{17}$ é um dos elementos da temático do exótico mais perceptíveis de ser reconhecido nas análises, pois como dito antes, caracteriza-se por ser um local distante do cotidiano dos enunciatários. No caso das fotografias do site, o longínquo é encarnado pela cidade de Curitiba, que é mimetizada e representada nas figuras da estrutura arquitetônica da Ópera do Arame e da Estufa do Jardim Botânico e pela natureza do Parque Tanguá. Esse longínquo, igualmente pode ser associado a incontáveis outros espaços turísticos, que por sua vez, tendem a remeter os observadores das fotos turísticas, logo, os enunciatários do site Curitiba Turismo, para uma das máximas do turismo: o escape na fuga do cotidiano.

\section{A figurativização fotográfica da alteridade}

Não obstante, o longínquo só se materializará a partir das figuras de alteridade de um Outro. No caso destas análises, em formas plásticas (figuras) desconhecidas que representam o mundo estrangeiro, ou seja, nas fotos que compõem o display do site da urbe curitibana da Ópera do Arame, do Parque Tanguá e da Estufa do Jardim Botânico. Trata-se da visualização de uma somatória de diferenças objetivas e subjetivas que o eu (do enunciatário) percebe no Outro turístico (Curitiba), mimetizado por figuras visuais coloridas da cultura e da natureza nas fotos do site. Assim, estabelece-se uma relação entre alteridade e exotismo nas diferenças que surgem entre eles (Ferrari, 2003; Amirou, 2007; Landowiski, 1997. Freitas, 1987).

\section{A figurativização fotográfica dos alhures}

Os alhures no turismo se caracterizam por se formarem como a outra parte vivente da cena turística, algo que está noutro lugar, mas tem existência real ou imaginária no Outro turístico. Representam um tipo de desinteresse do enunciatário olhar o de lá, o que está na cena turística, sem estar por lá. Cabem as figurativizações corporificadas nas fotografias do site do destino turístico Curitiba operarem neste sentido, e assim, produzirem os alhures. Igualmente, estimulam um "vaivém do olhar do observador 
que olha da sua realidade cotidiana" para a superfície do banner, passando de "imagem para imagem, ou seja, do Mesmo dos leitores aos Outros turísticos" (Ferrari, 2013: 323).

O incentivar o movimento de olhar promove um tipo de proteção imaginária diminuindo o enfretamento com o objeto exótico e atua como se fosse uma bolha protetora que abriga o imaginário dos enunciatários em um espaço fantasioso explicitado por Amirou (2007). Como resultado "as distâncias diminuem e o ambiente que os separa (os leitores desse Outro turístico) é praticamente extinto e o longínquo se reduz ao próximo, ou seja, a mônada de seus Mesmos" Ferrari (2013: 323). Consequentemente, os alhures se alojam no olhar dos enunciatários e sobrepujam o empecilho da distância geográfica, para dessa forma, apropriar-se dele e unificá-lo em seu espaço (Freitas, 1987).

\section{A figurativização fotográfica do estranho}

As três fotografias do banner também expressam sentidos de mais um elemento formante do exotismo para que Curitiba se estabeleça como destino exótico: o diferente, isto é, aquilo que causa estranheza ao olhar. Na foto da Ópera do Arame, a intenção do enunciador é revelar uma figura arquitetônica única, ou seja, dessemelhante de outros equipamentos usuais urbanos. Sua visualização tende a ser inquietante, consequentemente, apreendida como exótica pelo enunciatário. Igualmente, a visualização da foto do grande e imponente paredão de pedras do Parque Tanguá refletido nas águas do lago, é uma vista ímpar e diferente para se fruir neste destino. Essa imagem é coroada no topo por figuras de algumas árvores e uma pequena estrutura arquitetônica que brilha no entardecer do dia. Sobretudo, pode-se sugerir que essa foto destaca, a partir do enquadramento fotográfico, uma sensação visual que contempla à imponência da natureza encravada no coração da cidade de Curitiba. Já na foto da Estufa do Jardim Botânico, o tratamento técnico fotográfico visa, mais ainda, euforizar o seu conhecido aspecto diferente de ser: bela e exótica. Portanto, essa fotografia usada no site foi capturada por um ângulo diferente dos tradicionalmente utilizados na promoção do atrativo, ou seja, os fundos da estrutura, numa suave diagonal e em um enquadramento aberto para propiciar uma visão ampla do entorno arborizado. Essa cena de visão panorâmica também privilegia a luz do entardecer, onde os raios dourados do sol cromatizam e iluminam a fotografia e causam uma sensação visual de calor e acolhimento, isto é, de hospitalidade.

\section{A figurativização fotográfica do sagrado}

O elemento imaginário do sagrado no turismo simboliza uma tendência humana de se adorar o misterioso e o fascinante entendido como uma qualidade do diferente. Trata-se do exótico materializado na fascinação que as pessoas sentem até hoje ao viajar para encontrá-lo. Nas antigas religiões os lugares eram penetrados pelo elemento exótico e os homens veneravam a natureza, pois neles viviam os espíritos que poderiam suavizar seus infortúnios e preservar suas saúdes. Para Amirou (2007: 53) são alguns significados atribuídos à força sagrada presente nesses sítios que até hoje mobilizam o deslocamento das pessoas que procuram neles reviver a "sensação perdida de uma presença plena de mistério". Esta característica do sagrado explica o motivo do distanciamento e da eliminação dos signos que lembram o contexto do cotidiano, e se exprime na preferência e na frequência das pessoas visitarem certos destinos turísticos específicos, uma vez que lhes são conferidas virtudes regenerativas, eletivas e sedutoras como locais sagrados: montanhas, florestas, cachoeiras, entre tantos outros sítios pródigos da natureza (Amirou, 2007).

Amirou (2007) ainda evidencia que são consagrados os lugares onde o homem provou, em conjunto com a natureza, tanto a sua força quanto a sua fraqueza, ratificando sua condição humana. Igualmente, as grandes concretizações da humanidade como as pirâmides, as catedrais, os grandes monumentos etc. ilustram à ideia do sagrado e do culto ao exótico. Neste sentido, as fotografias usadas no banner revelam um conjunto de figuratividades que conjugam a pujança da natureza e o vigor das realizações arquitetônicas do homem. A grandeza da natureza é exposta na fotografia do Parque Tanguá, em que o exótico sagrado se transforma em um convite visual à fruição do meio ambiente natural e presente neste atrativo turístico. Nas outras duas fotos, também se figurativiza à ambiência natural, no entanto, deve-se destacar que é à força da criatividade humana materializada nestas imagens que realiza o convite a experimentação do sagrado.

\section{Posicionamento do destino turístico}

São os arranjos plásticos formados pelos elementos cromáticos, topológicos e eidéticos que criam um diferencial para os lugares como exóticos, no caso destas análises, de Curitiba, visando o posicionamento das marcas turísticas. É por meio dessas visualizações fotográficas que o enunciador produz discursos 
visuais, logo realidades, mas também instituí interações com os públicos alvos e acende à promessa de prazer, hedonismo e felicidade exótica nos destinos (Perez, 2006; Semprini, 2006).

Assim sendo, oferece-se midiaticamente, receitas educativas de como o consumidor-turista deve perceber (ver) e vivenciar (sentir) qualquer destino turístico, consequentemente, engendrando o olhar turístico (Ferrari, 2013).

Como exposto, o olhar turístico ocorre por meio da visualização (o fazer ver) de fotografias que retratam lugares paradisíacos, longínquos, sagrados e diferentes do cotidiano. Logo, são locais exóticos, e que estão fora da cena social (Mesmos), onde esses viajantes estão inseridos. Assim, projeta-se, mercadologicamente, fantasias e sonhos exóticos que habitarão o imaginário dos turistas, interpretados pelo olhar do visitante como lugares autênticos, ou seja, um local ideal para eles manifestarem o eu e provarem à alteridade do Outro, por meio da viagem perfeita.

\section{A figurativização fotográfica do paraíso turístico}

Normalmente, a ideia do paraíso é dele ser repleto por paisagens bonitas, tropicais e insulares, numa visão fantasiosa do jardim do Éden. É no ideal do paraíso que as pessoas se revitalizam, se comunicam com o divino, portanto, lá não é um local de trabalho, não existem doenças, ou mortes, um lugar onde o homem é imortal (Aoun, 2010).

Ferrari (2013: 149) destaca que o imaginário do paraíso se estende à simples noção de apenas possuir paisagens exuberantes e tropicais e, pode ser "projetado em diversas formas no real: o terrestre, o celeste, o das compras, dos jogos, o fiscal e o das viagens". Em contrapartida, Amirou (2007) explica que essa idealização do paraíso, como espaço de vida perfeito, compõe o núcleo da imaginação turística e gira em torno de dois alicerces: o imaginário do paraíso como metáfora da felicidade e o de bem-estar de uma sociedade laicizada. Este paraíso de perfeição é midiaticamente representado por cenas na visualidade de simulacros turísticos, os quais operam na imaginação das pessoas provocando a fantasia, a excitação e o desejo de tornarem-se turistas. É difundido por um efeito estésico através de figurativizações paradisíacas nas fotografias, e tende a ativar o imaginário turístico dos enunciatários.

Nas três fotografias analisadas do site Curitiba Turismo, esse paraíso turístico celebra o consórcio harmônico entre à natureza e à cultura, mas com peculiaridades distintas. A foto da Ópera do Arame, conforma-se como o Paraíso dos Espetáculos. Um local, especialmente concebido para promover sinestesias corporais nas plateias e, possíveis somente em espaços que congreguem a união com à natureza exuberante. Nesta foto, a figura dos alicerces da estrutura de metal forma um desenho circular preenchido por luzes que provocam uma sensação visual de ser uma aliança de brilhantes. Assim, simboliza-se às bodas entre à cultura e à natureza. Essa apreensão visual é ratificada no espelho d'agua do lago composto pelos reflexos das luzes e sombras de árvores e exaltam a ambiência exótica desse paraíso turístico. Já a fotografia do Parque Tanguá é composta por várias formas da natureza (pedras, vegetação, lago, etc.) distribuídas na imagem que projetam à ideia de ser o Paraíso do Lazer Natural, curitibano. No último, fotograma se observa o Paraíso Botânico, mimetizado pela Estufa do Jardim Botânico, resultado da capacidade criativa da união entre cultura e plantas.

\section{A figurativização fotográfica de beleza paradisíaca}

A beleza paradisíaca é promovida por meio da composição de elementos cromáticos, topológicos e eidéticos figurativizados nas fotografias turísticas. Por sua vez, essas imagens tendem a propiciar uma fruição estética-estésica de sentidos do belo aos observadores. Às vezes, essa beleza expressa nos instantâneos é constituída por arranjos de traços simétricos, outras não. Pode ser figurativizada por paisagens da natureza e urbanas ou na composição de ambas. As figuras podem também simbolizar heroísmo, tristeza e mazelas da sociedade encontradas nos memoriais, nos cemitérios, nas favelas, nos campos de concentração etc. (Hiernaux-nicolas, 2012; ferrari, 2013).

Nas figurativizações do banner todas as três fotos são selecionadas para serem apreendidas pelos observadores como belas imagens. A ênfase pode ser a natureza, expressa na foto do Parque Tanguá, ou celebrar a cultura e a natureza, figuradas na imagem da Ópera do Arame. Já na fotografia da Estufa do Jardim Botânico, o realce é dado à beleza extravagante da estrutura arquitetônica.

\section{A figurativização fotográfica do espaço dos jogos e do jogo de identidade}

Os paraísos turísticos também são espaços de jogos, onde os viajantes podem vivenciar os aspectos lúdicos e fantasiosos do eu. Eles são divididos em espaços-reais, configurados por recintos recreativos, 
parques naturais e temáticos, estádios, navios, resorts, praias etc. e, também em espaços-virtuais voltados à encenação de múltiplas identidades (Amirou, 2007; Ferrari, 2013).

Todas as fotos que cobrem o display do site Curitiba Turismo são apreendidas pelo olhar dos visitantes como espaços-reais, recintos demarcados por equipamentos de lazer da cidade, locais onde eles poderão fruir às qualidades verdes de Curitiba. São também espaços-virtuais, onde esses sujeitos poderão vivenciar a alteridade reduzida de ser curitibano ao se projetarem nesse simulacro midiático.

\section{A figurativização fotográfica da felicidade exótica}

A figurativização da felicidade exótica é apreendida como uma síntese visual dos sentidos que o prazer e hedonismo podem gerar nos espaços-reais-virtuais do turismo. Para surtir esses sentidos, as figuras das fotos devem ser, preferencialmente, coloridas, visando propiciar efeitos de realidade e remeter o imaginário do observador no afastamento do mundo cotidiano. Devem também, conter figuras de pessoas felizes e sorridentes, dias ensolarados, pôr do sol flamejantes, noites estreladas e reluzentes, etc. A diversão, o lazer e o entretenimento são projetadas nas temáticas das fotos e fazem parte da composição da figuratividade da felicidade exótica (Ferrari, 2013).

Entre as fotografias mostradas no site Curitiba Turismo, a que melhor exemplifica a felicidade exótica é a imagem da figura 2, a Ópera do Arame. As outras duas fotos, somente sugerem as possíveis temáticas de experiências de lazer. $\mathrm{Na}$ foto da Ópera de Arame, os valores de felicidade exótica são projetados por meio das luzes que cintilam em vários pontos da imagem e oferecem vida e movimento à cena turística. Dessa forma, promove-se midiaticamente um efeito visual sinestésico de prazer para o olhar do enunciatário. Por outro lado, a inexistência de figuras humanas e felizes nas três fotos é compensada pela fruição estésica de beleza paradisíaca, que, normalmente, envia o imaginário dos sujeitos para locais belos, vibrantes e harmoniosos: o mundo colorido do Turismo.

\section{A marca da viagem perfeita}

As apreensões de sentidos do olhar do visitante tendem a buscar sinais na visualização das fotos turísticas que materializem uma viagem ideal. Portanto, as marcas turísticas por meio de suas produções de sentidos atuam no nível da suspensão do real em direção ao universo onírico de um Outro Turístico, com a intenção de fazer crer aos seus interpretes que o consumo desses produtos são o caminho de acesso ao mundo sensível e desejável de prazeres e alegrias (Ferrari, 2013). Deste modo, ao se analisar o banner do site do destino turístico Curitiba, verificou-se que os esforços comunicacionais visando à construção da marca turística são dirigidos na produção de um efeito de sentido mais abrangente, considerado a viagem perfeita.

\section{Considerações finais}

Ser um local paradisíaco e longínquo será à única figurativização e inscrição de sentidos do consumo do exótico no turismo? Como os sentidos do exótico são figurativizados nas fotografias de forma que se tornem em marcas turísticas em Curitiba?

Com esta pesquisa foi possível identificar que o apelo ao consumo do exótico no turismo é, antes de tudo, uma construção simbólica e faz parte das estratégias comunicacionais do marketing de destinos na projeção de imaginários turísticos da viagem perfeita. Também foi possível ratificar que é no turismo onde o exótico se mostra mais visível, por meio do uso de fotografias que mimetizam e representam a realidade cultural de um Outro. Assim estas estratégicas concebidas pelo setor turístico ocorrem porque os destinos necessitam se mostrarem diferentes e atrativos para se destacarem de incontáveis outros existentes, visando captar a atenção e a predileção dos consumidores-turistas.

Deste modo, averiguou-se que a constituição do imaginário do exótico no turismo é um complexo manancial discursivo (verbivisual) de produção de sentidos. Estes significados planam entorno de inscrições simbólicas que vão além das mais conhecidas como: o longínquo e o paradisíaco, contemplando também representações de alteridade, dos alhures, do estranho e do sacro. Tal conjunto simbólico, por sua vez, desmembra-se nos sentidos discursivos da beleza paradisíaca, dos jogos e o jogo de identidade e da felicidade exótica. Essa totalidade discursiva atua sobre a sensibilidade do Outro consumidor-turista e tende a provocar a fantasia e o sonho de poder provar (consumir) em uma única experiência a viagem perfeita. Igualmente, comprovou-se que para materializar esse imaginário exótico, alguns cuidados devem ser adotados na seleção das fotografias que serão utilizadas nas estratégias comunicacionais 
do marketing de destino. As representações das fotos devem oferecer arranjos visuais que acionem o imaginário do exótico nos observadores, mas objetivando provocar estesias (sensações corporais) em suas apreensões sensíveis. Especialmente, devem convocá-los provar (viajar) e fruir o destino. Isso só é possível por meio de semiotizações eficientes que privilegiem figurativizações que contenham os elementos simbólicos do exótico, de forma a torná-lo um diferencial do destino. Ou seja, posicionando o destino turístico como um local diferente para o consumidor-turista fruir e partilhar com seus pares valores socialmente importantes de status, prazer, felicidade, liberdade, etc.

A partir desse estudo, demonstrou-se por meio de um modelo de análise de que maneira o olhar do consumidor-turista é construído mercadologicamente visando a identificação de inscrições exóticas na visualização do Outro turístico. Portanto, concluiu-se a necessidade de afastar investidas comunicacionais exclusivamente voltadas para o uso de fotografias consideradas apenas na perspectiva de serem bonitas e coloridas. Ao contrário, deve-se buscar reconhecer, além desse simples aporte estético visual um conjunto de sentidos dos elementos exóticos nelas amalgamado. Assim sendo, é vital para os gestores do turismo saber identificar o quanto estes traços exóticos estão ou não incrustrados nas superfícies fotográficas e se, realmente, esses sentidos produzidos visualmente podem atuar na sensibilidade sensorial dos potenciais consumidores como um diferencial dos destinos turísticos para torná-los marcas de sucesso, ou seja, construir a marca da viagem perfeita, o ideal, desde sempre, de todo viajante. Para tanto, o modelo de análise apresentado neste estudo pode ser utilizado por gestores visando o aprimoramento do marketing de destino e como um escopo à inovação de novas estratégias.

Neste sentido, foi possível diagnosticar que a principal tática comunicacional adotada pelo site Curitiba Turismo é mostrar imagens da urbe visando, sobretudo, ressignificá-la com intuito de torná-la mais atrativa. Para realizar essa estratégia, o enunciador-governamental se utilizou de imagens fotografias diferentes das tradicionais à promoção dos atrativos, com a finalidade de captar a atenção dos seus potenciais consumidores e provocar o desejo de experienciá-la. Assim, o enunciador-governamental tentou posicionar essa urbe como diferente de outros destinos turísticos que detêm as mesmas características e, assim, conceber uma marca de viagem perfeita para o destino turístico Curitiba.

\section{Agradecimentos}

Os autores agradecem ao CNPq pelo financiamento desta pesquisa por meio da bolsa de Pós-doutorado - PNPD, no período de junho de 2014 a maio de 2015, realizado no Programa de Pós-Graduação em Turismo, da Universidade Federal do Paraná.

\section{Bibliografia}

Amirou, R.

2007. Imaginário Turístico e Sociabilidades de Viagem. Porto: Editora Estratégias Criativas.

Aoun, S.

2001. "A procura do paraíso no universo do turismo". Disponível em: www.naya.org.ar/turismo_cultural/ congreso/.../sabah_aoun.htm. Acessado em: 11.02.2014.

Curitiba Turismo.

2016. Disponível em: www.turismo.curitiba.pr.gov.br/ Acessado em: 16.02.2016.

Barros, D. L.P.

2004. "Publicidade e Figurativização". Disponível em: seer.fclar.unesp.br/alfa/article/viewFile/4294/3882

Acessado em: 02.08.2016.

Berghe V. D., P, Keys, C. F

1984. "Introduction: tourism and re-created ethnicity". Annals of Tourism Research, 11: 343-352.

Ferrari, C. M. M.

2013. A visualidade nos contratos comunicativos em revistas de turismo: construção de imaginários para turistas. Tese de Doutorado. Pontifícia Universidade Católica de São Paulo, PUCSP, São Paulo. Ferrari, C. M. M., Gândara, J.M

2015. "Fotografias de Viagens: replicando cenas da viagem perfeita em Curitiba". Caderno Virtual de Turismo, 15 (2): 112-130. 
Floch, J-M.

2001a. Semiotcs, Marketing and Comunication: beneath the signs, the strategies. New York: Palgrave Macmillan.

Floch, J-M.

2001b. Alguns conceitos fundamentais em semiótica geral. São Paulo: Edições CPS.

Freitas, M. T.

1998. "Exotismo e alteridade: de Blaise". Disponível em: http://www.revistas.usp.br/revusp/article/ viewFile/28413/30269 Acessado em: 27.03.2015.

Greimas, A. J.

1976. Semântica estrutural. São Paulo: Cultrix.

Greimas, A. J \& Courtés, J.

2008. Dicionário de Semiótica. (7 ed). São Paulo: Contexto.

Houaiss, A. \& Villar, M.

2001. Dicionário Houaiss da Língua Portuguesa. Rio de Janeiro: Objetiva.

Hiernaux-Nicolas, D.

2002. "Turismo e Imaginarios". In: Hiernaux-Nicolas, Daniel at all. Imaginarios sociales e turismo sostenible. Disponível em: www.biblioteca.clacso.edu.ar/ar/libros/costar/cua123.pdf. Acessado em: 10.10.2016.

Landowski, E.

1997. Presenças do Outro. São Paulo: Editora Perspectiva.

Landowski, E.

2009. Interaciones arriesgadas. Lima: Fondo Editorial.

Lucena, I. T.

2000. "Procedimentos de Revestimentos Semânticos e Construção do Sentido". In: Revista Graphos. v.5, n1: 33- 48 Disponível em: www.ies.ufpb.br/ojs2/index.php/graphos/article/view/9343/5023_Acessado em: 02.05.2016.

Loose, E. B. \& Peruzzolo, A. C.

2008. "Como o Meio Ambiente é tematizado no Discurso Jornalístico da Folha de S. Paulo". In: Intercom - Sociedade Brasileira de Estudos Interdisciplinares da Comunicação, XXXI Congresso Brasileiro de Ciências da Comunicação - Natal, RN. Disponível em: www.intercom.org.br/papers/nacionais/2008/ resumos/R3-0018-1.pdf Acessado em: 30.03.2016.

Mello, C. M. \& Gândara, J. M.

2015. "Los discursos fotográficos de los viageiro. Curitiba - Brasil en Tripadvisor". Estudios y Perspectivas, 24: $609-627$

Pietroforte, A.V.

2010. Semiótica visual: os percursos do olhar. 2 ed. São Paulo: Contexto.

Pietroforte, A.V.

2008. Análise do texto visual: a construção da imagem. São Paulo: Contexto.

Perez, C.

2006. Signos da Marca: expressividade e sensorialidade. São Paulo: Thompson Learning.

Piscitelli, A.

2002. "Exotismo e autenticidade: relatos de viajantes à procura do sexo". Disponível em: www.scielo. br/pdf/cpa/n19/n19a09.pdf Acessado em: 20.01.2016.

Santos, R. J

2013. “O ‘étnico' e o 'exótico': notas sobre a representação ocidental da alteridade”. Revista Rosa dos Ventos, 5 (4): 635-643.

Saraniemi, S., Kylanen, M.

2010. "Problematizing the concept of tourism destination: An analysis of different theoretical approaches". Journal of Travel Research, 50 (2): 133-143.

Segalen, V.

1989. Ensayo sobre el exotismo: uma estética de lo diverso y textos sobre Gauguin y Oceania. Trad. Jorge Ferreiro, 1 ed. Mexico: Fondo de Cultura Economica.

Semprini, A.

2006. A marca pós-moderna: poder e fragilidade da marca na sociedade contemporânea. São Paulo: Estação das Letras Editora.

Urry, J.

1997. O olhar do turista: lazer e viagens nas sociedades contemporâneas. (3.ed). São Paulo: Studio Nobel. 


\section{Notas}

1 Landowiski (1997) explica que esse Outro não deve ser considerado, somente, o estrangeiro, o marginal, o excluído, mas também é aquele que dá forma à identidade do sujeito ao produzir significados de diferenças e, consequentemente, de comparação, de construção de diálogos objetivos e/ou subjetivos que dão sentidos à presença dos sujeitos no mundo.

2 No contexto desta pesquisa adota-se a definição de destino turístico como "um conjunto de instituições e atores localizados em um espaço físico ou virtual, onde transações e atividades mercadologicamente orientadas ocorrem, modificando a tradicional dicotomia entre produção e consumo" Saraniemi \& Kylanen (2010: 213). Tradução livre.

3 Ancorado em um pensamento semiótico, de linha francesa, o semioticista italiano, Andrea Semprini (2009) é reconhecido especialista na área de pesquisa de mercado e consultoria em identidade de marcas.

4 Clotilde Perez (2006) é importante semioticista brasileira com experiência nas áreas de pesquisas em comunicação, semiótica, consumo, publicidade, marca, criatividade e tendências sociais.

5 A semiótica greimasiana, ou francesa foi desenvolvida por A. J. Greimas (1976). É uma Teoria da Significação, em que o enfoque está no processo de significação capaz de gera-lo. Pode ser aplicada a todos os sistemas de linguagem (verbal, imagético, artes plásticas, cinematográfica, etc.) em qualquer época.

6 Jean-Marie Floch, como discípulo de Greimas, dedicou-se em seus estudos às linguagens visuais, aplicando o conceito da semiótica visual, ao estudo das artes plásticas, da comunicação, do marketing, do gosto, entre outros.

7 Vicente Pietroforte (2008; 2010) é um dos seguidores de Floch no Brasil e explora os conceitos da semiótica visual em seus estudos.

8 Cynthia Ferrari (2013) investigou em sua tese de doutoramento como as revistas de turismo, ao expor imagens fotográficas e desenvolver contratos comunicativos sobre a viagem perfeita, modalizam os consumidores-enunciatários na construção de imaginários de modo que os destinos turísticos sejam figurativizados a partir dessa perfeição. Tratou-se de estudar também, nessa perspectiva, as estratégias utilizadas pelos enunciadores midiáticos a construção de imaginários para a fruição da experiência turística.

9 Rachid Amirou dedicou-se a estudar os imaginários turísticos.

10 Hiernaux-Nicolas (2012) apresenta neste estudo como o distanciamento das análises tradicionais das práticas turísticas podem ser adensadas, por meio de uma abordagem subjetiva através da criação dos imaginários do turismo.

11 Tereza Freitas (1987) trata das questões relativas ao exotismo e a alteridade, das imagens do Outro.

12 O livro "Ensaios sobre o exotismo" é uma obra clássica de Victor Segalen (1989) e abarca o exotismo numa perspectiva da estética do diverso (o sentir), uma tentativa de revitalizar esse conceito. O autor extrai do termo exotismo a sua conotação de tropical e estranho, mas igualmente, o aproxima do sentido etnológico da palavra, que associa alteridade e exotismo. Para ele o exotismo é o sentimento do homem em relação à diversidade, a ideia do diferente e da alteridade e ao comportamento deste, frente ao diferente e estranho.

13 "Abreviação do latim versus (= contra), vs. é um símbolo convencional, utilizado para designar oposição a relação de oposição quando não está determinada" (Greimas \& Courtés, 2008: 537).

14 Com base nas pesquisas em Ferrari (2013); Aoun (2010); Amirou (2007); Semprini (2006); Perez (2004); Hiernaux-Nicolas (2002); Landowski (1997); Urry (1997); Segalen, (1989); Freitas (1987).

15 Tradução livre.

16 "Esse outro, que nomeamos como o Outro turístico, é aquele que conjuga e congrega tanto a primeira superfície do mundo humano (cultura e natureza) quanto a segunda, os sentidos dos valores da primeira, em um tempo-espaço previamente estabelecido para práticas socioculturais de lazer e entretenimento. A função desse Outro turístico é articular a busca de uma dimensão do 'si' ligada à plenitude do ser através da produção de sentidos e de possíveis alteridades representadas por eles" (FERRARI, 2013: 54).

17 Concepção elaborada com base em Ferrari (2013); Amirou (2007); Freitas (1987). 